\title{
PENGARUH KETIDAKAMANAN KERJA, KETERLIBATAN KARYAWAN DAN DUKUNGAN ORGANISASI TERHADAP KINERJA KARYAWAN DENGAN KOMITMEN ORGANISASIONAL SEBAGAI VARIABEL INTERVENING PADA KARYAWAN BAGIAN PRODUKSI BULU MATA PALSU PT. COSMOPROF INDOKARYA DI KABUPATEN BANJARNEGARA
}

\author{
Tyasih Sukma Pawestri, Ari Pradhanawati \\ Administrasi Bisnis, Universitas Diponegoro, Indonesia \\ Email: janis@undip.ac.id
}

\begin{abstract}
The performance of employees the production of eyelashes PT. Cosmoprof Indokarya shown at an average of the results of each employee in the years 2013-2015 tends to fluctuate. The target of production is set by the company is 1.56 million pairs of eyelashes, but only about 1.4 million pairs of eyelashes can be produced. To deal with the problem is to determine what factors are causing the employee's performance did not reach the target. The high levels of stress and perceived environmental changes employees will create a sense of insecurity that can affect the performance degradation. Lack of organizational support received by employees will affect their performance. When employees are participating in the work and do not have a strong desire to survive in the organization will decrease the performance of the employee. This is also shown by the employee turnover rate of $20 \%$ by year. This study aims to identify and analyze the effects of job insecurity, employee engagement, organizational support and organizational commitment to employee performance and organizational commitment partially as an intervening variable. Researchers ask 10 (ten) hypothesis in this study. This type of research is a quantitative research study classification based on objective being explanatory, where statistics were used to analyze the sample data and results will be generalizable to populations where samples were taken. The population in this study were all employees of the production PT.Cosmoprof Indokarya as many as 941 employees and the number of samples 91 employees. Data were analyzed using SEM-PLS and use data analysis tools SmartPLS 3.0. The data analyzed comes from distributing questionnaires to employees. Results of testing the coefficient of SEM analysis showed that: (HI) is rejected; (H2) is received; $(H 3)$ is received; $(H 4)$ is received; $(H 5)$ is received; $(H 6)$ was rejected; (H7) is received; $(H 8)$ is rejected; $(H 9)$ was rejected; $(H 10)$ is rejected. The results of the study explains there are some weak indicators of each variable job insecurity, employee engagement, organizational support, organizational commitment, and employee performance. It is recommended that companies to review, evaluation, and give motivation and training on employees in order to improve their capabilities.
\end{abstract}

Kinerja karyawan bagian produksi bulu mata PT. Cosmoprof Indokarya ditunjukan pada rata-rata hasil produksi tiap karyawan di tahun 2013-2015 cenderung fluktuatif. Target produksi yang ditetapkan perusahaan adalah 1.560 .000 pasang bulu mata, namun hanya sekitar 1.400.000 pasang bulu mata yang mampu dihasilkan. Untuk menangani masalah tersebut adalah dengan mengetahui faktor apa saja yang menyebabkan kinerja karyawan tidak mencapai target. Tingginya tingkat tekanan dan perubahan lingkungan yang dirasakan karyawan akan menciptakan rasa tidak aman yang dapat mempengaruhi penurunan kinerja. Kurangnya dukungan organisasi yang diterima karyawan juga akan mempengaruhi kinerja mereka. Ketika karyawan kurang berpartisipasi dalam pekerjaan dan tidak memiliki keinginan yang kuat untuk bertahan pada organisasi akan berdampak pada menurunnya kinerja karyawan. Hal ini juga ditunjukan dengan tingkat turnover karyawan yang mencapai $20 \%$ per tahun. Penelitian ini bertujuan untuk mengetahui dan menganalisis pengaruh ketidakamanan kerja, keterlibatan karyawan, dukungan organisasi dan komitmen organisasional terhadap kinerja karyawan secara parsial dan komitmen 
organisasional sebagai variabel intervening. Peneliti mengajukan 10 (sepuluh) hipotesis dalam penelitian ini. Jenis penelitian yang digunakan merupakan penelitian kuantitatif dengan klasifikasi penelitian berdasarkan tujuannya yaitu eksplanatory, dimana statistik yang digunakan untuk menganalisis data sampel dan hasilnya akan digeneralisasikan untuk populasi dimana sampel diambil. Populasi dalam penelitian ini adalah seluruh karyawan bagian produksi PT.Cosmoprof Indokarya yaitu sebanyak 941 karyawan dan jumlah sampel 91 orang. Teknik analisis data menggunakan SEM-PLS dan menggunakan alat analisis data SmartPLS 3.0. Data yang dianalisis berasal dari penyebaran kuesioner kepada karyawan. Hasil pengujian koefisien dari analisis SEM menunjukkan bahwa: (H1) ditolak; (H2) diterima; (H3) diterima; (H4) diterima; (H5) diterima; (H6) ditolak; (H7) diterima; (H8) ditolak; (H9) ditolak; (H10) ditolak. Hasil penelitian menjelaskan ada beberapa indikator yang lemah dari masing-masing variabel ketidakamanan kerja, keterlibatan karyawan, dukungan organisasi, komitmen organisasional, dan kinerja karyawan. Disarankan agar perusahaan meninjau dan mengevaluasi serta memberikan motivasi dan pelatihan pada karyawan agar meningkatkan kemampuan yang telah dimiliki.

\section{Keywords \\ Job Insecurity, Employee Engagement, Organizational support, Organizational Commitment, Employee Performance. \\ Ketidakamanan Kerja, Keterlibatan Karyawan, Dukungan Organisasi, Komitmen Organisasi, Kinerja Karyawan.}

\section{Pendahuluan}

Era globalisasi telah melanda berbagai aspek kehidupan manusia. Kemajuan teknologi informasi dan komunikasi terbukti mampu merubah dunia menjadi lebih terbuka akan persaingan ketat. Kondisi ini menyebabkan menurunnya persentase penggunaan tenaga kerja dalam perusahaan. Perusahaan banyak memanfaatkan berbagai alat produksi hasil teknologi tinggi seperti mesin-mesin produksi, komputer dan mekanisme lainnya. Hal tersebut menciptakan pergeseran fungsi tenaga kerja dalam operasionalisasi perusahaan. Namun teknologi secanggih apapun jika tanpa sumber daya manusia maka akan sulit untuk perusahaan dalam mencapai tujuannya. Oleh sebab itu sumber daya manusia menurut pandangan Gomes (2003 :9) dapat menjadi pusat segalanya kegiatan dalam suatu organisasi dan harus dikembangkan potensi-potensinya secara wajar dan meyakinkan. Namun berbeda dengan sumber daya manusia yang mempunyai keinginan dan kebutuhan, baik fisik maupun non-fisik. Kebutuhan sumber daya manusia jika terpenuhi secara wajar maka dengan sendirinya akan memberikan kontribusi bagi keberhasilan organisasi.

Tujuan dari setiap perusahaan adalah mendapatkan keuntungan. Namun, dengan adanya perubahan dan persaingan ekonomi yang semakin ketat dan bebas, maka perusahaan harus menjaga eksistensinya untuk dapat mencapai hasil yang maksimal, maka perusahaan harus lebih memperhatikan karyawan atau tenaga kerjanya dengan menyeimbangkan antara keinginan dan harapan mereka. Sehingga menciptakan kinerja karyawan yang lebih optimal.

Untuk menghasilkan kualitas produk yang diinginkan perusahaan harus bisa memberdayakan tenaga kerja atau karyawannya dengan baik. Tuntutan standar kualitas, peraturan dan berbagai hal menyebabkan perusahaan dan karyawan harus saling mendukung sehingga tercipta kualitas kerja yang baik yang nantinya akan berpengaruh terhadap kualitas produk yang dihasilkan setiap karyawan.

Menurut pandangan Mathis \& Jackson (2006:113) bahwa faktor-faktor 
yang mempengaruhi kinerja seseorang individu adalah dukungan organisasi serta tingkat usaha yang dicurahkan. Dengan demikian kemampuan karyawan dalam menerapkan ilmu melalui kecerdasan intelektual yang dimilikinya dan diterapkan dalam pekerjaan akan menghasilkan kinerja dalam pekerjaannya. Tingkat usaha yang dicurahkan dalam pekerjaan ditujukan dengan keterlibatan karyawan dalam menghadapi pekerjaan.

Pada dasarnya karyawan adalah manusia yang mempunyai perasaan, batas kelelahan dan tingkat kebosanan terhadap pekerjaan. Karyawan bukanlah mesin yang dapat digerakkan terus-menerus tanpa suatu penghargaan. Jika karyawan telah mencapai tingkat kebosanan dan kelelahan maka mereka akan malas bekerja dan perhatian mereka pada kerjaan berkurang sehingga mereka akan cenderung melakukan kesalahankesalahan. Hal tersebut tidak dapat dibiarkan terlalu lama, karena akan berdampak pada kinerja karyawan dan perusahaan.

Beberapa faktor yang menyebabkan penurunan kinerja ini diantaranya adalah faktor ketidakamanan kerja, faktor tersebut adalah sebuah ancaman yang menyebabkan efek negatif yang dapat mempengaruhi penurunan pada komitmen organisasional dan kinerja karyawan. Ketidakamanan kerja merupakan tekanan yang dirasakan karyawan karena adanya permasalahan yang ada dalam pekerjaannya. Beberapa hal yang menjadi sumber permasalahan kerja antara lain: kondisi pekerjaan, konflik peran, dan lokus kendali (Suhartono, 2007:61).

Faktor kedua adalah keterlibatan karyawan, faktor keterlibatan karyawan merupakan sejauh mana seorang individu penuh perhatian dan memahami perannya dalam bekerja (Saks, 2006). Keterlibatan karyawan adalah sikap positif yang ditunjukan para karyawan dengan berpartisipasi terhadap perusahaannya, mampu menunjukan pekerjaan sebagai hal yang utama, dan melihat pekerjaan sebagai sesuatu yang penting untuk harga dirinya.
Faktor ini memberikan dorongan positif pada karyawan, sehingga meningkatkan komitmen organisasional dan kinerja karyawan itu sendiri.

Faktor ketiga adalah dukungan organisasi yang diterima karyawan, dimana dukungan organisasi dipandang sebagai kerangka penjelasan penting untuk memahami hubungan antara karyawan dan tempat kerja, dan dianggap banyak peneliti merupakan usaha yang berfokus dalam memahami sikap dan perilaku seorang karyawan yang berkaitan dengan pekerjaan. Dukungan organisasi adalah sejauh mana karyawan menilai organisasi mereka memberikan dukungan dan peduli terhadap kesejahteraan karyawannya. Ketika karyawan merasa perusahaan berlaku adil, adanya dukungan atasan, serta adanya penghargaan terhadap karyawan hal ini akan mendorong karyawan dalam meningkatkan komitmen organisasional dan kinerja karyawan.

Faktor keempat adalah komitmen organisasional. Menurut pendapat Luthans, (2006:249), komitmen organisasional merupakan tingkat dimana tenaga kerja atau karyawan mempunyai keinginan yang kuat untuk terus menjadi anggota sebuah organisasi, dan dalam upaya mencapai tujuan dan nilai sebuah organisasi maka mereka harus berusaha keras untuk mencapai keinginan tersebut. Sehingga ketika komitmen organisasional itu tinggi maka karyawan akan berusaha bekerja lebih baik lagi sehingga dapat meningkatkan kinerja karyawan tersebut.

\section{Kajian Teori}

\section{Kinerja Karyawan}

Mathis \& Jackson (2006:65)
menjelaskan pada dasarnya kinerja
(performance) adalah apa yang dilakukan
atau tidak dilakukan oleh karyawan.
Misalnya dalam elemen kinerja dikenal
dengan adanya kualitas, kuantitas,
ketepatan waktu dengan hasil, selain itu
kehadiran serta kemampuan dalam
bekerjasama.


Sedangkan Hasibuan (2013:94) menjelaskan lebih rinci pandangannya tentang kinerja, bahwa kinerja merupakan capaian hasil kerja dalam menjalankan tugas berdasarkan kecakapan, kesungguhan kecakapan dan waktu.

Berdasarkan pengertian diatas, dapat disimpulkan bahwa kinerja karyawan merupakan kemampuan individu dalam mencapai syarat pekerjaan, yaitu individu dapat menyelesaikan target kerja secara tepat waktu atau tidak melebihi batas waktu yang ditentukan sehingga tujuan akan sesuai dengan etika perusahaan. Sehingga kinerja karyawan dapat memberikan kontribusi bagi perusahaan.

\section{Ketidakamanan Kerja (Job Insecurity)}

Menurut pandangan Greenhalgh \& Rosenblatt, 1984 (dalam Goksoy, 2012), ketidakamanan kerja adalah persepsi atau pandangan individu/ karyawan mengenai ketidakberdayaan untuk mempertahankan keinginan kelangsungan pekerjaan dalam situasi pekerjaan yang terancam.

Ashford et.al (1989) berpendapat bahwa ketidakamanan kerja (job insecurity) mencerminkan perasaan karyawan tentang pekerjaan mereka terancam dan merasa tidak berdaya untuk melakukan segalanya tentang itu.

Dari pengertian ketidakamanan kerja tersebut, maka definisi ketidakamanan kerja adalah perasaan tidak berdaya yang dialami oleh karyawan karena adanya situasi yang memberikan tekanan baik dari lingkungan internal maupun eksternal yang membuat posisi pekerjaan karyawan tersebut terancam.

Keterlibatan Karyawan ( Employee Engagement)

Menurut Robbins (2006:268) keterlibatan karyawan adalah proses partisipasi yang menggunakan seluruh kapasitas karyawan yang dirancang untuk mendorong meningkatkan komitmen demi kesuksesan organisasi.

Saks (dalam Albdour \& Altarawneh, 2014), menemukan perbedaan arti antara pekerjaan dan organisasi engagement (job engagement dan organization engagement), dimana karakteristik pekerjaan itu meramalkan job engagement dan keadilan prosedural organization engagement.

Berdasarkan pengertian beberapa ahli tersebut, maka dapat disimpulkan bahwa keterlibatan karyawan adalah suatu kondisi dimana karyawan terlibat atau berpartisipasi secara aktif terhadap pekerjaannya karena karyawan merasa yakin terhadap organisasi.

\section{Dukungan Organisasi (Organizational Support)}

Dukungan organisasi mengacu pada persepsi karyawan mengenai sejauh mana organisasi menilai kontribusi, memberi dukungan, dan peduli pada kesejahteraan mereka (Rhoades \& Eisenberger, 2002).

Selanjutnya Eisenberger dan Rhoades (2002) menjelaskan lebih rinci bahwa dalam upaya meningkatkan kepercayaan organisasi maka harus ada penilaian yang positif dari organisasi tersebut sehingga karyawan akan memberikan perhatian yang lebih atas penghargaan yang mereka terima dari atasan mereka.

Dari pengertian diatas, maka dapat disimpulkan bahwa dukungan organisasi adalah persepsi atau pandangan karyawan terhadap dukungan organisasi yang diterimanya, seperti keadilan yang diberikan oleh organisasi, kepedulian atasan terhadap bawahannya, serta kepedulian sesama rekan kerja.

\section{Komitmen Organisasional (Organizational Commitment)}

Komitmen organisasional didefinisikan sebagai tingkat di mana seorang karyawan percaya dan menerima tujuan organisasi dan keinginan untuk tinggal dengan organisasi (Mathis, 2008:70).

Chen (2008) mendefinisikan komitmen organisasional sebagai pendekatan psikologis karyawan terhadap organisasi mereka. Komitmen organisasi berhubungan positif dengan kepuasan 
kerja, motivasi dan kinerja, berhubungan negatif dengan absen dan niat untuk pindah.

Konsep tentang komitmen karyawan terhadap organisasi ini (disebut pula komitmen kerja), yang mendapat perhatian dari manajer maupun ahli perilaku organisasi, berkembang dari studi awal mengenai loyalitas karyawan yang diharapkan ada pada setiap karyawan.

Dari pengertian diatas dapat disimpulkan bahwa komitmen organiasional adalah suatu ikatan psikologis para karyawan terhadap organisasinya dengan ditandai rasa percaya dan penerimaan yang kuat terhadap nilai dan tujuan organisasi, kemauan untuk bekerja keras demi tercapainya kepentingan organisasi, serta keinginan yang kuat untuk bertahan sebagai anggota organisasi.

\section{Metodologi Penelitian}

Penelitian ini menggunakan pendekatan kuantitatif. Sedangkan teknik pengumpulan data menggunakan kuesioner. Lokasi penelitian di PT Cosmoprof Indokarya Kabupaten Banjarnegara.

Jenis penelitiannya eksplanasi yaitu metode untuk menjelaskan suatu pengaruh suatu variabel dengan variabel lainnya (Prasetyo \& Jannah, 2012:43).

Populasi dalam penelitian ini adalah karyawan bagian produksi bulu mata palsu PT. Cosmoprof Indokarya Banjarnegara sebanyak 941 karyawan. Penentuan sampel menggunakan rumus dari Slovin yaitu sebesar 91 responden. Data penelitian dianalisis menggunakan Partial Least Square (PLS).

\section{Hasil}

Data penelitian ini diolah menggunakan software SmartPLS3.0, yaitu model dieksekusi menggunakan PLS Algorithm dan Bootstrapping. Berikut ini adalah tampilan dari PLS

Algorithm dan Bootstrapping (Ghozali, 2011):

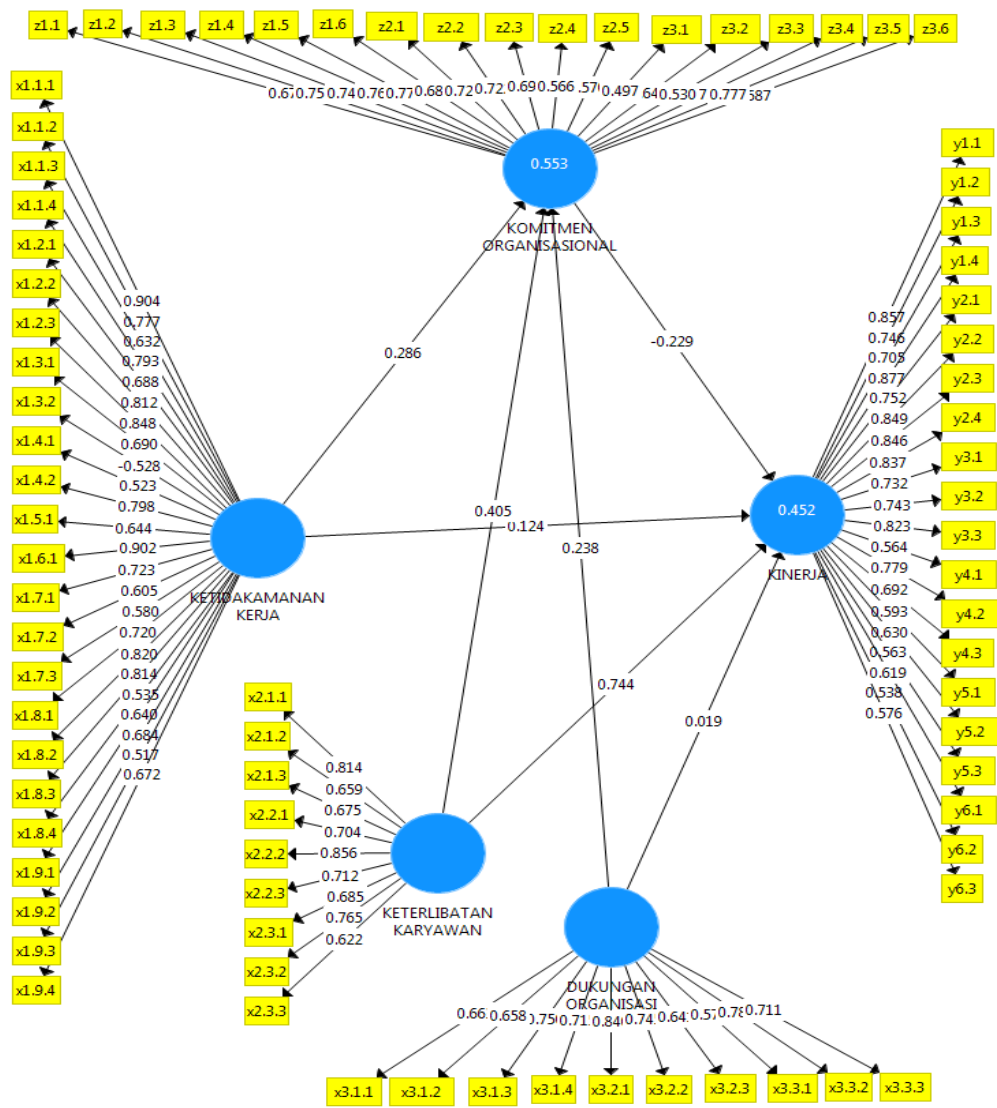

Gambar 1.

PLS Algorithm Tahap 1 
85 | Jurnal Administrasi Bisnis Volume 6 Nomor 2 September 2017

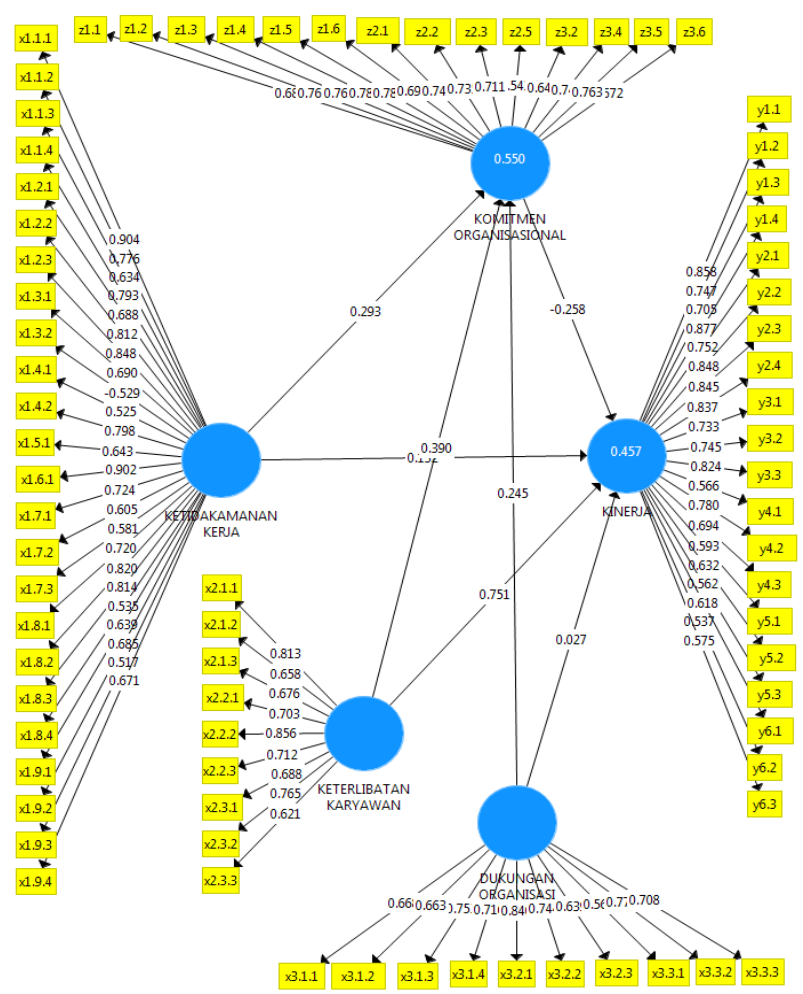

Gambar 2.

PLS Algorithm Tahap 2

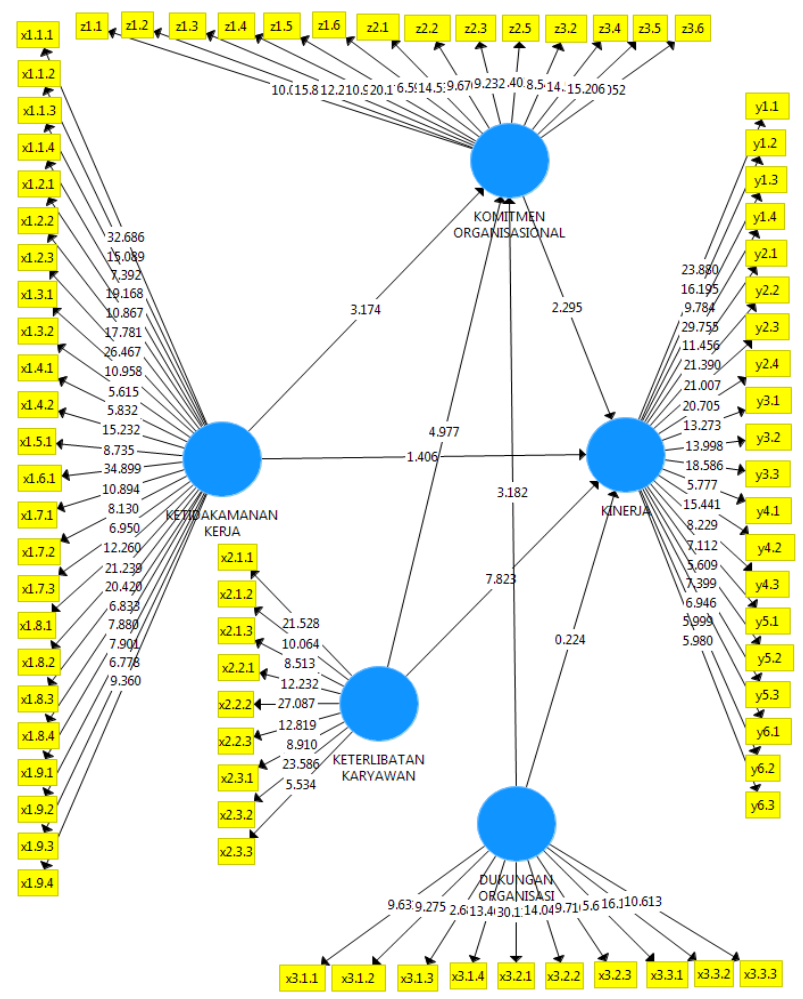

Gambar 3

Bootstrapping 


\section{Pembahasan}

\section{Pengaruh Ketidakamanan Kerja Terhadap Kinerja Karyawan}

Hasil analisis dengan menggunakan SEM-PLS untuk hipotesis pertama menunjukkan bahwa ada pengaruh signifikan antara ketidakamanan kerja terhadap kinerja karyawan, bahwa ketidakamanan kerja berpengaruh secara tidak signifikan terhadap kinerja karyawan artinya ketidakamanan kerja pengaruhnya dapat dikatakana tidak berarti terhadap kinerja karyawan. Dengan dibuktikan t-hitung 1,406 < t-tabel 1,96 dan sig $>5 \%$. Sehingga hipotesis pertama "terdapat pengaruh signifikan antara ketidakamanan kerja terhadap kinerja karyawan" ditolak.

Dengan demikian karena hipotesis pertama ditolak maka hasil penelitian ini tidak sejalan dengan hasil penelitian Reisel, et.al (2007) yang menunjukan bahwa ketidakamanan kerja memiliki pengaruh kuat terhadap kinerja. Staufenbiel \& Konig (2010) juga mengemukakan dalam hasil penelitiannya antara ketidakamanan kerja dengan kinerja karyawan memiliki pengaruh yang signifikan.

Secara empiris dapat ditemukan beberapa kondisi pada PT. Cosmoprof Indokarya yang menyebabkan, bahwa ketidakamanan kerja berpengaruh secara tidak signifikan terhadap kinerja karyawan. Alasannya, Pertama, melihat indikator dari variabel ketidakamanan kerja yang memiliki nilai ketidakamanan kerja paling tinggi adalah pekerjaan yang sulit diselesaikan dengan nilai mean 2,70. Hal tersebut menunjukan bahwa ketidakamanan kerja pada PT.Comoprof Indokarya lebih menonjol pada aspek seorang karyawan yang merasa sangat sulit menyelesaikan pekerjaannya, yang ditunjukan dengan $41 \%$ responden setuju dan $5 \%$ responden sangat setuju mengalami hal tersebut. Indikator ketidakmanan kerja ini belum cukup untuk mempengaruhi kinerja karyawan jika dibandingkan dengan indikator lain seperti perasaan takut dipecat, atau raguragu mempertahankan pekerjaan, bisa juga karena pendapatan yang tidak menjanjikan, upah yang tidak dibayarkan, ruang kerja kotor dan bau, ruang kerja kurang pencahayaan, pekerjaan yang dapat menimbulkan stress berkepanjangan, ketidakjelasan prosedur tugas, tekanan pekerjaan, perasaan bersalah meninggalkan tugas sebagai ibu rumah tangga, kegagalan yang dialami karena kurang kerja keras atas kemampuan sendiri, karyawan tidak bertanggung jawab atas keputusan yang dipilih, ketidakmampuan kontrol diri jika terjadi perubahan, perencanaan jauh kedepan adalah pekerjaan sia-sia. Kedua, ketidakamanan kerja yang dinilai dalam penelitian ini adalah ketidakamanan yang dirasakan oleh karyawan dengan tingkat pendidikan rendah sehingga tanggung jawab kerja yang diberikan tidak terlalu tinggi. Hal ini ditunjukan dengan mayoritas responden memiliki pendidikan terakhir SMP yaitu sebesar 40\%. Faktor ketiga, dapat ditemukan bahwa mayoritas umur responden dari karyawan bagian produksi PT.Cosmoprof Indokarya adalah berusia 21-25 tahun, dimana usia tersebut masih tergolong dalam usia produktif artinya ketika karyawan mendapat ancaman dalam pekerjaan mereka tidak terlalu khawatir karena merasa masih mampu untuk mencari pekerjaan lain.

\section{Pengaruh Ketidakmanan Kerja Terhadap Komitmen Organisasional}

Berdasarkan hasil analisis SEM-PLS untuk pengujian hipotesis kedua, terdapat pengaruh yang signifikan antara ketidakamanan kerja terhadap komitmen organisasional, bahwa ketidakamanan kerja berpengaruh signifikan terhadap komitmen organisasional. Hal tersebut dibuktikan dengan nilai t-hitung 3,174 > t-tabel 1,96 dan sig $<5 \%$. Sehingga bunyi dari hipotesis kedua "terdapat pengaruh signifikan antara ketidakamanan kerja terhadap komitmen organisasional" diterima.

Hasil penelitian ini juga tidak sejalan dengan penelitian Asford (1989), yang menemukan ketidakamanan kerja berhubungan signifikan dengan penurunan komitmen. Penelitian De Witte (2005) menjelaskan bahwa karyawan yang merasa 
tidak aman akan kurang berkomitmen terhadap perusahaannya.

Secara empiris dapat ditemukan beberapa kondisi pada PT. Cosmoprof Indokarya yang menyebabkan ketidakamanan kerja berpengaruh positif secara signifikan terhadap komitmen organisasional. Pertama, dengan melihat beberapa indikator ketidakamanan kerja, meskipun karyawan merasa ruang kerja panas dan sempit, pekerjaan terlalu banyak, pekerjaan sulit diselesaikan, pekerjaan menimbulkan stress berkepanjangan, atasan terlalu banyak menuntut, perasaan sangat lelah setelah bekerja, keyakinan atas perlakuan tidak adil oleh perusahaan, kegagalan yang dialami karena faktor ketidakberuntungan serta kejadian dalam pekerjaan ditentukan oleh orang yang berkuasa tetapi karyawan tetap memilih bertahan bekerja pada perusahaan. Hal ini ditunjukan dengan data responden yang menunjukan masa kerja karyawan paling rendah adalah 3 tahun. Kedua, sebesar 64\% responden telah menikah. Dengan status tersebut karyawan akan memilih bertahan di perusahaan daripada harus mencari pekerjaan baru karena merasa terbebani atau memiliki tanggungan untuk memenuhi kebutuhan rumah tangga.

\section{Pengaruh Keterlibatan Karyawan Terhadap Komitmen Organisasional}

Hipotesis ketiga yang dianalisis dengan menggunakan SEM-PLS menyatakan bahwa terdapat pengaruh yang signifikan antara keterlibatan karyawan terhadap komitmen organisasional, yang menunjukan bahwa keterlibatan karyawan berpengaruh signifikan terhadap komitmen organisasional. Hal tersebut dibuktikan dengan nilai t-hitung senilai 4,977> t-tabel senilai 1,96 dan sig < $5 \%$. Sehingga hipotesis ketiga, "terdapat pengaruh signifikan antara keterlibatan karyawan terhadap komitmen organisasional" diterima.

Pada penelitian ini menunjukan bahwa karyawan PT.Cosmoprof Indokarya memiliki faktor kepedulian terhadap pekerjaan, dimana sebesar $69 \%$ responden menjawab baik dan $26 \%$ responden menjawab sangat baik.
Artinya bahwa karyawan merasa peduli terhadap pekerjaannya yang ditunjukan dengan bekerja keras dalam menyelesaikan tugasnya dengan teliti dan memperhatikan kerapihan hasil bulu matanya. Ketika karyawan merasa peduli terhadap pekerjaannya, akan mendorong karyawan untuk bekerja keras sehingga dapat membantu kesuksesan organisasi, hal ini sejalan dengan komitmen organisasional karyawan yang ditunjukan sebesar 57\% responden mampu dengan baik dan $16 \%$ responden mampu sangat baik dalam ketersediaannya bekerja keras demi membantu kesuksesan organisasi.

Faktor pekerjaan adalah hal utama dimana sebesar $65 \%$ responden menjawab baik dan 29\% responden menjawab sangat baik. Artinya bahwa karyawan memiliki kesadaran yang tinggi untuk menyelesaikan pekerjaannya karena semakin banyak bulu mata yang sesuai standar yang dihasilkan maka semakin banyak penghasilan yang mereka dapatkan. Hal ini sejalan dengan hasil komitmen organisasional karyawan yang ditunjukan sebesar $57 \%$ responden menjawab baik dan sebesar 7\% responden menjawab sangat baik, bahwa karyawan merasa rugi karena akan kehilangan penghasilan jika meninggalkan pekerjaannya.

Faktor penguasaan bidang pekerjaan yang menjadi bagiannya dimana sebesar $71 \%$ responden menjawab baik dan $23 \%$ responden menjawab sangat baik. Artinya bahwa karyawan merasa mampu menguasai tugasnya sehingga dapat menyelesaikan tugas dengan baik. Hal ini sejalan dengan hasil komitmen organisasional dalam melaksanakan tugas sesuai keinginan organisasi yang ditunjukan sebesar $48 \%$ responden menjawab baik dan 9\% responden menjawab sangat baik, bahwa karyawan mampu melaksanakan tugas sesuai keinginan perusahaan.

Faktor bertanggung jawab atas pekerjaan dimana sebesar $67 \%$ responden menjawab baik dan $24 \%$ responden menjawab sangat baik. Artinya bahwa karyawan mampu melaksanakan pekerjaannya tanpa harus diawasi. Hal ini sejalan dengan hasil komitmen organisasional karyawan yang ditunjukan dengan 52\% responden menjawab 
baik dan hanya $7 \%$ responden yang menjawab sangat baik, yaitu karyawan merasa memiliki organisasi.

Hasil tersebut memberikan makna bahwa karyawan bagian produksi PT.Cosmoprof Indokarya yang memiliki faktor kepedulian terhadap pekerjaan, menganggap pekerjaan sebagai hal penting atau utama, mampu menguasai bidang pekerjaan yang menjadi tugasnya, serta bertanggung jawab terhadap pekerjaannya akan mendorong mereka untuk lebih berpartisipasi dalam pekerjaannya. Ketika karyawan berpartisipasi dalam pekerjaannya, karyawan akan lebih termotivasi dan meningkatkan komitmen mereka.

Hasil penelitian ini mendukung penelitian Albdour \& altarawaneh (2014), yaitu keterlibatan karyawan memiliki pengaruh kuat dengan komitmen organisasional. Semakin tinggi keterlibatan karyawan maka semakin tinggi pula komitmen organisasionalnya. Sejalan dengan teori dalam Robbins (2006:268) bahwa dengan melibatkan karyawan maka keputusan-keputusan tentang mereka dengan cara meningkatkan kendali atas kehidupan kerja mereka, maka para karyawan akan lebih termotivasi dan lebih berkomitmen dengan pekerjaan mereka.

\section{Pengaruh Keterlibatan Karyawan Terhadap Kinerja Karyawan}

Hipotesis keempat, ada pengaruh yang signifikan antara keterlibatan karyawan terhadap kinerja karyawan telah diuji. Hal tersebut dibuktikan melalui penelitian dengan nilai t-hitung senilai 7,823>t-tabel senilai 1,96 yang menunjukan bahwa keterlibatan karyawan memiliki pengaruh signifikan terhadap kinerja karyawan. Sehingga hipotesis pertama yang berbunyi "terdapat pengaruh signifikan antara keterlibatan karyawan terhadap kinerja karyawan" diterima.

Penelitian ini juga menjelaskan bahwa karyawan pada PT.Cosmoprof Indokarya memiliki faktor kepedulian terhadap pekerjaan, dimana sebesar 69\% responden menjawab baik dan 26\% responden menjawab sangat baik. Artinya bahwa karyawan merasa peduli terhadap pekerjaannya yang ditunjukan dengan bekerja keras dalam menyelesaikan tugasnya dengan teliti dan memperhatikan kerapihan hasil bulu matanya. Hal ini sejalan dengan penilaian hasil kinerja karyawan bahwa sebesar 58\% responden dinilai mampu dengan baik dan 12\% responden dinilai mampu dengan sangat baik menyelesaikan bulu mata dengan teliti dan rapi.

Faktor pekerjaan adalah hal utama dimana sebesar $65 \%$ responden menjawab baik dan 29\% responden menjawab sangat baik. Artinya bahwa karyawan memiliki kesadaran yang tinggi untuk menyelesaikan pekerjaannya karena semakin banyak bulu mata yang sesuai standar yang dihasilkan maka semakin banyak penghasilan yang mereka dapatkan. Serta dengan berupaya selalu bekerja tepat waktu. Hal ini sejalan dengan hasil penilaian kinerja karyawan bahwa sebesar $60 \%$ responden dinilai baik dan $4 \%$ responden dinilai sangat baik, bahwa karyawan memiliki kesadaran tinggi yang ditunjukan dengan kerja kerasnya dalam menghasilkan bulu mata.

Faktor penguasaan bidang pekerjaan yang menjadi bagiannya dimana sebesar $71 \%$ responden menjawab baik dan $23 \%$ responden menjawab sangat baik. Artinya bahwa karyawan merasa mampu menguasai tugasnya sehingga dapat menyelesaikan tugas dengan baik. Hal ini sejalan dengan hasil penilaian kinerja karyawan yang ditunjukan sebesar $61 \%$ responden dinilai baik dan $2 \%$ responden dinilai sangat baik, bahwa karyawan mampu menyelesaikan tugasnya tanpa bantuan orang lain.

Faktor bertanggung jawab atas pekerjaan dimana sebesar $67 \%$ responden menjawab baik dan $24 \%$ responden menjawab sangat baik. Artinya bahwa karyawan mampu melaksanakan pekerjaannya tanpa harus diawasi. Hal ini sejalan dengan hasil penilaian kinerja karyawan yang ditunjukan dengan $62 \%$ responden dinilai baik dan $3 \%$ responden dinilai sangat baik, bahwa karyawan mampu bekerja dan menyelesaikan pekerjaan tanpa harus diawasi. 
Analisis di atas menjelaskan, bahwa karyawan bagian produksi PT. Cosmoprof Indokarya yang memiliki faktor kepedulian terhadap pekerjaan, menganggap pekerjaan sebagai hal utama, mampu menguasai bidang pekerjaan yang menjadi tugasnya, dan bertanggung jawab terhadap pekerjaannya karena akan mendorong mereka untuk lebih berpartisipasi dalam pekerjaannya. Sehingga ketika karyawan melibatkan diri dalam pekerjaannya maka karyawan akan lebih produktif dengan demikain kinerja karyawannya akan meningkat.

Penelitian ini sejalan dengan teori dalam Robbins (2006:268) bahwa dengan melibatkan karyawan dalam mengambil keputusan mengenai mereka dengan cara meningkatkan kendali atas kehidupan kerja mereka, sehingga para karyawan lebih termotivasi dan mempunyai komitmen yang tinggi dengan pekerjaan mereka sehingga akan meningkatkan kinerja karyawan tersebut.

\section{Pengaruh Dukungan Organisasi Terhadap Komitmen Organisasional}

Hipotesis kelima, terdapat pengaruh signifikan antara dukungan organisasi terhadap komitmen organisasional telah diuji. Hal tersebut dibuktikan melalui penelitian dengan nilai t-hitung senilai 3,182 > t-tabel senilai 1,96 yang menunjukan bahwa dukungan organisasi memiliki pengaruh signifikan terhadap komitmen organisasional. Sehingga hipotesis kelima yang berbunyi "terdapat pengaruh signifikan antara dukungan organisasi terhadap komitmen organisasional" diterima.

Pada penelitian ini menunjukan bahwa karyawan bagian produksi PT.Cosmoprof Indokarya memiliki persepsi tentang dukungan organisasi yang diterimanya. Pertama, bonus lembur dimana $47 \%$ responden menjawab sangat baik dan 38\% responden menjawab baik. Artinya bahwa karyawan merasa puas dan senang jika perusahaan selalu memberikan bonus ketika karyawan bekerja lembur. Kedua, kebijakan pro karyawan dimana $22 \%$ responden menjawab sangat baik dan $64 \%$ responden menjawab baik. Artinya bahwa karyawan merasa kebijakan yang dikeluarkan perusahaan sudah memberi keuntungan bagi karyawan. Seperti mendapatkan bonus ketika lembur, mendapatkan ijin ketika hamil. Ketiga, pemenuhan peralatan guna menunjang pekerjaan dimana $19 \%$ responden menjawab sangat baik dan $67 \%$ responden menjawab baik. Artinya bahwa karyawan merasa akan bekerja lebih maksimal ketika diberikan perlatan kerja yang bagus dan memadai. Keempat, jaminan kesehatan dimana $49 \%$ responden menjawab baik dan 39\% reponden menjawab sangat baik. Artinya bahwa karyawan merasa aman bekerja dalam perusahaan ketika mendapat asuransi atau jaminan kesehatan. Kelima, evaluasi kinerja dimana $42 \%$ responden menjawab sangat baik dan $32 \%$ responden menjawab baik. Artinya bahwa karyawan merasa senang dan lebih dihargai ketika diperhatikan dan dinilai hasil kerjanya oleh atasan. Keenam, pujian dari atasan dimana $33 \%$ responden menjawab sangat baik dan $43 \%$ responden menjawab baik. Artinya bahwa karyawan akan merasa gembira dan semakin giat bekerja karena atasan sering memberi dukungan dan pujian atas hasil yang dicapai karyawan.

Hasil penelitian juga dapat memberikan makna untuk karyawan bagian produksi PT. Cosmoprof Indokarya memiliki penilaian mengenai dukungan organisasi yang diterimanya itu berdampak positif terhadap komitmen organisasional mereka. Dan ketika dukungan organisasi itu tinggi maka komitmen organisasional meningkat. Penelitian ini sejalan dengan penelitian Panaccio \& Vandenberghe (2009) bahwa hubungan antara dukungan organisasi dengan komitmen organisasional menunjukan bahwa dukungan organisasi memiliki hubungan yang signifikan dengan komitmen organisasional.

\section{Pengaruh Dukungan Organisasi Terhadap Kinerja Karyawan}

Hipotesis keenam yang menyatakan bahwa terdapat pengaruh signifikan antara dukungan organisasi terhadap kinerja karyawan telah diuji. Hal tersebut dibuktikan melalui penelitian dengan nilai t-hitung senilai $0,224<$ t-tabel senilai 1,96 dan sig > 
5\% yang menunjukan bahwa dukungan organisasi berpengaruh secara tidak signifikan terhadap komitmen organisasional. Sehingga hipotesis keenam yang berbunyi "terdapat pengaruh signifikan antara dukungan organisasi terhadap kinerja karyawan" ditolak.

Mengacu pada sisi kualitas jawaban yang diberikan responden atas item pertanyaan terkait dengan dukungan organisasi didapatkan bahwa ada $23 \%$ responden menjawab kurang baik dan responden lainnya sebesar $7 \%$ menjawab tidak baik pada indikator pengakuan organisasi. Artinya bahwa karyawan merasa pengakuan organisasi terhadap keberadaannya kurang begitu penting bagi mereka. Karena keterbatasan pendidikan, sehingga membuat mereka beranggapan bahwa mendapatkan penghasilan atau upah saja sudah cukup bagi mereka. Indikator bantuan atas kesulitan ditunjukan sebesar $25 \%$ responden menjawab kurang baik, artinya bahwa karyawan merasa tidak selalu mendapatkan bantuan atas kesulitan yang dialami seperti pertengkaran dengan rekan kerja, kesulitan menyelesaikan bulu mata sesuai target, ataupun masalah keuangan mereka. Indikator pembayaran gaji atau upah ditunjukan sebesar $24 \%$ responden menjawab kurang baik dan $6 \%$ responden menjawab tidak baik, artinya bahwa karyawan merasa pembayaran gaji yang diberikan belum sesuai dengan kerja keras yang mereka keluarkan. Indikator pelatihan dimana sebesar $17 \%$ responden menjawab kurang baik dan sebesar $6 \%$ responden menjawab tidak baik, artinya bahwa karyawan merasa dengan pelatihan yang diberikan belum sepenuhnya membantu mereka dalam meningkatkan ketrampilan atau keahlian dalam bidangnya. Dikarenakan waktu penyelenggaraan pelatihan yang terbatas. Hal tersebut mengindikasikan bahwa secara umum tingkat dukungan organisasi yang dirasakan karyawan bagian produksi PT.Cosmoprof Indokarya yang diukur dari item pertanyaan yang diajukan cukup rendah. Secara empiris kurangnya pengaruh dukungan organisasi terhadap kinerja dapat disebabkan beberapa hal, pertama dapat ditemukan bahwa mayoritas tingkat pendidikan dari responden adalah lulusan SMP dan SD. Dengan tingkat pendidikan yang rendah membuat para karyawan tidak memikirkan dan peduli dengan hal-hal lain dalam pekerjaan selain harus bekerja agar mendapatkan upah untuk mencukupi kebutuhan mereka sehari-hari. Kesimpulannya, bahwa dukungan organisasi yang dirasakan karyawan masih belum cukup memiliki pengaruh yang signifikan terhadap kinerja mereka.

\section{Pengaruh Komitmen Organisasional Terhadap Kinerja}

Hipotesis ketujuh, terdapat pengaruh yang signifikan antara komitmen organisasional terhadap kinerja karyawan telah diuji. Hal tersebut dibuktikan melalui penelitian dengan nilai t-hitung senilai 2,295 $>$ t-tabel senilai 1,96 yang menunjukan komitmen organisasional memiliki pengaruh signifikan terhadap kinerja karyawan. Sehingga hipotesis ketujuh "terdapat pengaruh signifikan antara komitmen organisasional terhadap kinerja karyawan" diterima.

Penelitian ini menjelaskan karyawan bagian produksi PT. Cosmoprof Indokarya memiliki faktor komitmen organisasional, dimana karyawan merasa melekat dengan organisasi yang ditunjukan dengan 57\% responden menjawab baik dan $16 \%$ responden menjawab sangat baik. Artinya bahwa karyawan bersedia sangat keras dalam membantu kesuksesan perusahaan dengan melakukan pekerjaan dengan tepat waktu, menghasilkan bulu mata dengan teliti dan rapi, serta berusaha menyelesaikan target jumlah produksi bulu mata yang ditetapkan perusahaan. Karyawan gembira bekerja pada organisasi dimana sebesar $64 \%$ responden menjawab baik dan $8 \%$ responden menjawab sangat baik, artinya bahwa karyawan merasa gembira bekerja dalam perusahaan ini. Karyawan merasa gembira karena bisa mendapatkan penghasilan untuk memenuhi kebutuhan hidupnya, serta mendapat dukungan dari atasan, rekan kerja dan keluarganya. Setia pada organisasi dimana sebesar 52\% responden menjawab baik dan $10 \%$ responden menjawab sangat baik, artinya bahwa karyawan merasa bersedia untuk tetap setia bekerja dalam organisasi ini 
karena mereka membutuhkan pekerjaan agar dapat memperoleh penghasilan untuk memenuhi kebutuhan hidupnya. Merasa memiliki organisasi dimana sebesar $52 \%$ responden menjawab baik dan $6 \%$ responden menjawab sangat baik, artinya bahwa karyawan merasa senang ketika menceritakan kepada keluarga maupun orang lain bahwa perusahaan ini merupakan perusahaan hebat sebagai tempat bekerja. Bangga terhadap organisasi dimana sebesar $63 \%$ responden menjawab baik dan $12 \%$ responden menjawab sangat baik, artinya bahwa karyawan merasa bangga bisa bekerja di perusahaan ini, karena dengan bekerja disini karyawan mampu memperoleh penghasilan yang kemudian bisa meningkatkan pola kehidupannya di lingkungan sosialnya. Melaksanakan tugas sesuai keinginan organisasi dimana sebesar $48 \%$ responden menjawab baik dan $9 \%$ responden menjawab sangat baik, artinya bahwa karyawan menerima semua tugas yang diberikan atasan karena untuk tetap bisa bekerja dalam perusahaan ini. Merasa rugi jika meninggalkan organisasi dimana sebesar $57 \%$ responden menjawab baik dan $6 \%$ responden menjawab sangat baik, artinya bahwa karyawan tidak akan meninggalkan perusahaan ini karena karyawan merasa akan kesulitan mencari pekerjaan lain dan kehilangan penghasilan mereka sehingga membuat mereka merasa rugi dan memutuskan untuk tetap bekerja di perusahaan ini. Khawatir dengan resiko dimana sebesar 59\% responden menjawab baik dan 6\% responden menjawab sangat baik, artinya bahwa karyawan merasa khawatir dengan resiko atau masalah yang harus dihadapi apabila meninggalkan perusahaan ini. Karyawan tidak bisa memenuhi kebutuhan hidupnya jika meninggalkan perusahaan ini karena mereka tidak yakin mampu mendapatkan pekerjaan baru setelah meninggalkan perusahaan ini. Tidak ada pilihan lain dimana sebesar $71 \%$ responden menjawab baik dan 5\% responden menjawab sangat baik, artinya bahwa karyawan merasa tidak mempunyai pilihan lain selain tetap bekerja pada perusahaan ini. Hal tersebut dikarenakan kebutuhan hidup yang semakin meningkat, tetapi status pendidikan yang dimiliki rendah, sehingga terbatas untuk mencari lapangan kerja yang baru. Mendapat keuntungan dimana sebesar $63 \%$ responden menjawab baik dan $10 \%$ responden menjawab sangat baik, artinya bahwa karyawan merasa banyak yang mereka peroleh dengan tetap bekerja pada perusahaan ini. Karyawan memperoleh penghasilan, mempunyai ketrampilan baru serta mendapat teman baru. Hal tersebut mengindikasikan bahwa secara umum tingkat komitmen organisasional yang dirasakan karyawan bagian produksi PT.Cosmoprof Indokarya yang diukur dari item pertanyaan yang diajukan cukup berpengaruh. Hasil penelitian ini mendukung teori atau temuan pada penelitian sebelumnya oleh Khan (2010) yang mengatakan bahwa komitmen seorang karyawan pada organisasi mempunyai pengaruh yang signifikan terhadap kinerja karyawan tersebut.

\section{Pengaruh Ketidakamanan Kerja Terhadap Kinerja Karyawan Melalui Komitmen Organisasional}

Hipotesis kedelapan yang menyatakan bahwa ada pengaruh signifikan antara ketidakamanan kerja terhadap kinerja karyawan melalui komitmen organisasional telah diuji. Hasilnya membuktikan bahwa dengan nilai t-hitung senilai $1,884<\mathrm{t}$-tabel senilai 1,96 yang menunjukan bahwa ketidakamanan kerja melalui komitmen organisasional berpengaruh secara tidak signifikan terhadap kinerja karyawan. Dengan demikian hipotesis kedelapan "terdapat pengaruh signifikan antara ketidakamanan kerja terhadap kinerja karyawan melalui komitmen organisasional" ditolak.

Dengan demikian dapat diambil kesimpulan bahwa komitmen organisasional memperlemah pengaruh dari ketidakamanan kerja terhadap kinerja karyawan. Meskipun komitmen organisasional itu diperlukan tetapi tidak cukup kuat untuk mendukung hasil kinerja. Sedangkan penelitian ini menjelaskan bahwa variabel ketidakamanan kerja terhadap kinerja karyawan melalui komitmen organisasional berpengaruh tidak signifikan. Sehingga dapat dijelaskan bahwa pengaruh mediasi tersebut termasuk dalam tidak ada mediasi. Tidak memediasi dapat disebutkan 
ketika variabel independen terhadap variabel dependen tidak memiliki pengaruh yang signifikan dan variabel independen terhadap variabel dependen melalui mediasi juga tidak signifikan. Hasil penelitian ini tidak sejalan dengan hasil penelitian Chirumbolo, (2005) yang menunjukan bahwa ketidakamanan kerja memiliki pengaruh terhadap kinerja dengan di mediasi oleh komitmen organisasional. Hal tersebut disebabkan oleh beberapa faktor seperti faktor demografis responden, jumlah sampel yang masih sedikit, data responden yang berbeda, pendidikan, masa kerja, serta status perkawinan.

\section{Pengaruh Keterlibatan Karyawan Terhadap Kinerja Karyawan Melalui Komitmen Organisasional}

Hipotesis kesembilan yang menyatakan terdapat pengaruh signifikan antara keterlibatan karyawan terhadap kinerja karyawan melalui komitmen organisasional telah diuji. Hal tersebut dibuktikan melalui penelitian dengan nilai t-hitung senilai 1,844 $<\mathrm{t}$-tabel senilai 1,96 yang menunjukan bahwa keterlibatan karyawan melalui komitmen organisasional berpengaruh secara tidak signifikan terhadap kinerja karyawan. Sehingga hipotesis kesembilan, "terdapat pengaruh signifikan antara keterlibatan karyawan terhadap kinerja karyawan melalui komitmen organisasional" ditolak.

Dengan demikian dapat diambil kesimpulan bahwa komitmen organisasional memperlemah pengaruh dari keterlibatan karyawan terhadap kinerja karyawan. Sekalipun keterlibatan karyawan berpengaruh terhadap komitmen organisasional. Meskipun komitmen organisasional itu diperlukan tetapi tidak cukup kuat untuk mendukung hasil kinerja. Dalam penelitian ini variabel keterlibatan karyawan terhadap kinerja karyawan melalui komitmen organisasional berpengaruh tidak signifikan. Berdasarkan hasil tersebut dapat dijelaskan bahwa pengaruh mediasi tersebut termasuk dalam mediasi parsial. Mediasi parsial dapat disebutkan ketika variabel independen mampu mempengaruhi secara langsung terhadap variabel dependen tanpa melalui variabel mediasi. Berdasarkan hasil penelitian tersebut dapat dinyatakan tidak sejalan dengan hasil penelitian Robbins (2006), bahwa keterlibatan karyawan menjadi salah satu faktor yang dapat mempengaruhi kinerja karyawan. Hingga keterlibatan para pekerja melalui keputusannya dalam meningkatkan kendali kehidupan kerja mereka, yang akhirnya karyawan akan lebih termotivasi, dan lebih berkomitmen, karena pada akhirnya akan mempengaruhi produktivitasnya dalam bekerja. Hal tersebut disebabkan oleh beberapa faktor seperti faktor dari demografis responden, jumlah sampel yang masih sedikit, data responden yang berbeda dari penelitian sebelumnya. Data responden seperti umur, pendidikan, masa kerja, status perkawinan.

\section{Pengaruh Dukungan Organisasi Terhadap Kinerja Karyawan Melalui Komitmen Organisasional}

Hipotesis kesepuluh, ada pengaruh yang signifikan antara dukungan organisasi terhadap kinerja karyawan melalui komitmen organisasional telah diuji. Hal tersebut dibuktikan melalui penelitian dengan nilai thitung senilai $1,940<$ t-tabel senilai 1,96 yang menunjukan bahwa dukungan organisasi melalui komitmen organisasional berpengaruh tidak signifikan terhadap kinerja karyawan. Dengan demikian hipotesis kesepuluh, "terdapat pengaruh signifikan antara dukungan organisasi terhadap kinerja karyawan melalui komitmen organisasional" ditolak.

Dengan demikian dapat diambil kesimpulan bahwa komitmen organisasional memperlemah pengaruh dari dukungan 'organisasi terhadap kinerja karyawan. Meskipun komitmen organisasional itu diperlukan tetapi tidak cukup kuat untuk mendukung hasil kinerja. Dalam penelitian ini variabel dukungan organisasi terhadap kinerja karyawan melalui komitmen organisasional berpengaruh tidak signifikan, artinya komitmen organisasional tidak mampu memediasi variabel dukungan organisasi terhadap kinerja karyawan. Berdasarkan hasil tersebut dapat dijelaskan bahwa pengaruh mediasi tersebut termasuk dalam tidak ada mediasi. Tidak memediasi dapat disebutkan ketika variabel independen terhadap variabel 
dependen memiliki pengaruh yang tidak signifikan dan variabel independen terhadap variabel dependen melalui mediasi juga memiliki pengaruh tidak signifikan. Hal tersebut disebabkan oleh beberapa faktor seperti faktor demografis responden, jumlah sampel yang masih sedikit, data responden seperti umur, pendidikan, masa kerja, status perkawinan.

\section{Kesimpulan dan Saran}

\section{Kesimpulan}

Variabel ketidakamanan kerja terhadap kinerja karyawan tidak berpengaruh signifikan terhadap kinerja karyawan. Sedangkan variabel ketidakamanan kerja terhadap komitmen organisasional berpengaruh signifikan terhadap komitmen organisasional karyawan. Variabel keterlibatan karyawan terhadap komitmen organisasional berpengaruh signifikan terhadap komitmen organisasional karyawan. Variabel keterlibatan karyawan terhadap kinerja karyawan berpengaruh signifikan terhadap kinerja karyawan. Variabel dukungan organisasi terhadap komitmen organisasional berpengaruh signifikan terhadap komitmen organisasional karyawan. Variabel dukungan organisasi terhadap kinerja karyawan tidak berpengaruh signifikan terhadap kinerja karyawan. Variabel komitmen organisasional terhadap kinerja karyawan berpengaruh signifikan terhadap kinerja karyawan. Variabel ketidakamanan kerja terhadap kinerja karyawan melalui komitmen organisasional tidak berpengaruh terhadap kinerja karyawan. Variabel keterlibatan karyawan terhadap kinerja karyawan melalui komitmen organisasional tidak berpengaruh terhadap kinerja karyawan. Variabel dukungan organisasi terhadap kinerja karyawan melalui komitmen organisasional tidak berpengaruh terhadap kinerja karyawan.

\section{Saran}

Saran untuk penelitian selanjutnya: ruang lingkup obyek penelitian diperluas, khususnya industri kerajinan kosmetika di Indonesia. Beberapa indikator dari variabel ketidakmanan kerja yang hasilnya tidak signifikan terhadap kinerja karyawan. Beberapa indikator dari variabel dukungan organisasi hasil tidak signifikan terhadap kinerja karyawan. Konstruk yang tidak valid, dan hipotesis mengenai pengaruh variabel independen terhadap variabel dependen melalui variabel mediasi (intervening) yang ditolak, sehingga disarankan pada penelitian yang akan datang dapat diperbaiki atau dibuktikan kembali dengan memperbesar sampel penelitian supaya dapat menggambarkan secara umum populasi dalam penelitian yang akan datang. Sehingga diharapkan agar permasalahan mengenai variabel tersebut diketahui lebih baik lagi. Sedangkan saran untuk perusahaan: variabel ketidakmanan kerja pada karyawan bagian produksi yang hasilnya tidak signifikan perlu ditinjau kembali faktor-faktornya agar nantinya tidak mempengaruhi kinerja karyawan. Diantaranya: ruang kerja yang panas dan sempit, pekerjaan terlalu banyak, pekerjaan sulit diselesaikan, pekerjaan menimbulkan stress berkepanjangan, atasan terlalu banyak menuntut, ketidakyakinan atas perlakuan adil oleh perusahaan, kegagalan yang dialami karyawan karena faktor ketidakberuntungan, kejadian dalam pekerjaan ditentukan oleh orang yang berkuasa, ketidaksuksesan karyawan karena faktor nasib. Peneliti menyarankan agar perusahaan meninjau kembali berkaitan dengan standar kualitas pembuatan bulu mata palsu untuk disesuaikan dengan kemampuan karyawan. Atau dengan memberikan pelatihan lebih khusus lagi terhadap karyawan agar meningkatkan ketrampilan mereka. Variabel komitmen organisasional mempunyai pengaruh negatif terhadap kinerja karyawan, maknanya bahwa ketika karyawan memiliki komitmen yang tinggi maka akan semakin menurunkan kinerja mereka. Hal ini disebabkan karyawan memilih bertahan dalam perusahaan adalah untuk mendapatkan penghasilan saja. Saran untuk perusahaan agar lebih memperhatikan karyawan untuk lebih dihargai, sehingga akan mendorong karyawan lebih menghargai organisasinya pula. Variabel keterlibatan karyawan memiliki pengaruh paling kuat diantara variabel lainnya. Sehingga diharapkan 
perusahaan dapat memperhatikan faktor tersebut untuk dapat diaplikasikan kepada para karyawan guna meningkatkan kinerja mereka.

\section{Daftar Referensi}

Albdour, A. A., \& Altarawneh, I. I. (2014). Employee Engagement and Organizational Commitment : Evidence from Jordan, 19(2).

Ashford, S. J., Lee, C., \& Bobko, P. (1989). Content, Causes, and Consequences of Job Insecurity: A Theory-Based Measure and Substantive Test. Academy of Management Journal, 32(4), 803-829.

Chen, F.H., Chen, C.Y . 2008. “ The Impact of Work Redesign and Psychological Empowerment on Organizational Commitment in a Changing Environment : An Examples From Taiwan's State Owned Enterprises". Public Personnel Management.

Chirumbolo, Antonio. 2005. The Influence of Job Insecurity On Job Performance And Absenteeism: The Moderating Effect Of Work Attitudes. Journal of Industrial Psychology, 31(4), pp.65-71.

Ghozali, I. (2011). Structural Equation Modeling: Metode Alternatif dengan Partial Least Square (PLS) (Edisi 3). Semarang: Badan Penerbit-UNDIP.

Goksoy, A. (2012). The Impact of Job Insecurity, Role Ambiguity, Self Monitoring and Perceived Fairness of Previous Change on Individual American University in Bulgaria Individual Readiness for Change, 102111.

http://doi.org/10.20460/JGSM.2012615 790

Gomes, F. (2003). manajemen sumber daya manusia (Edisi 11). Yogyakarta: Penerbit Andi.

Greenberg, J. (1987), a Taxonomy of Organizational Justice Theories, Academy of Management Review, 12 (1), pp. 9-22.
Hasibuan, M. S. . (2013). Manajemen Sumber Daya Manusia (Edisi Revi). Jakarta: Bumi Aksara.

Luthans, F. (2006). Perilaku Organisasi. (S. Purwanti, Ed.) (Edisi Sepu). Yogyakarta: Penerbit Andi.

Mathis, R. L., \& Jackson, J. H. (2006). Human Resource Management. (Palupi Wuliarti, Ed.) (Edisi Kese). Jakarta: Salemba Empat.

Panaccio, A., \& Vandenberghe, C. (2009). Perceived organizational support, organizational commitment and psychological well-being: A longitudinal study. Journal of Vocational Behavior, 75(2), 224-236. http://doi.org/10.1016/j.jvb.2009.06.00 2

Prasetyo, B., \& Jannah, L. M. (2012). Metode Penelitian Kuantitatif: Teori dan Aplikasi (Edisi 1). Jakarta: PT RajaGrafindo Persada.

Reisel, W. D., Maloles, C. M., \& Slocum, J. W. (2007). The Effects of Job Insecurity on Satisfaction and Perceived Organizational Performance, 106-116.

Rhoades, L., \& Eisenberger, R. (2002). Perceived Organizational Support: A Review of the Literature, 87(4), 698714. http://doi.org/10.1037//0021 9010.87.4.698

Robbins, S. P. (2006). Perilaku Organisasi. Jakarta: PT. Indeks Kelompok Gramedia.

Saks, A. M. (2006). Antecedents and consequences of employee engagement. http://doi.org/10.1108/0268394061069 0169

Staufenbiel, T; Konig, C J. 2010. "A model for the effects of job insecurity on performance, turnover intention, and absenteeism". Journal of Occupational and Organizational Psychology, 83:101-117 
95 | Jurnal Administrasi Bisnis Volume 6 Nomor 2 September 2017

Suhartono, R. (2007). Resign No Way. (W. Afiyanti, Ed.) (cetak 1). yogyakarta: media pressindo.

Witte, Hans De. 2005. Job Insecurity: Review of The International Literature on Definitions, Prevalence, Antecedents And Consequences. Journal of Industrial Psychology, 31(4):1-6.
Employee Empowerment and Intent to Quit Among Survivors of Restructuring and Downsizing." Institute of Behavioral and Applied Management. www.ibam.com/pubs/ibam 